\title{
Synergetyka a planowanie urbanistyczne i projektowanie architektoniczne
}

\author{
J. Krzysztof Lenartowicz \\ Instytut Projektowania Architektonicznego, Wydziat Architektury, \\ Politechnika Krakowska,e-mail:klenart@pk.edu.pl
}

Streszczenie: O ile pojęcie synergii jako współpracy istniało w społecznościach ludzkich od zawsze, to rozumienie filozoficzne i techniczne jako współdziałania różnych czynników, którego efekt jest większy niż suma poszczególnych oddzielnych działań, nadał XXw. (H. Van Lier 1962, H. Haken 1969, R. Buckmister Fuller 1969). Synergetyka to uogólnienie synergii, uniwersalna teoria i metodologia, której przedmiotem są prawa samoorganizacji świata. W Polsce pierwsze opracowania tematu pojawiają się w latach 70. (Kotarbiński, Lenartowicz, Pszczołowski, Böhm). W artykule przedstawiono trzy rodzaje synergii związane z projektowaniem architektonicznym / planowaniem urbanistycznym: 1) Synergia formy przestrzennej. Efektem jest ład przestrzenny, zorganizowane uformowanie elementów tworzące całość. 2) Synergia dialogu społecznego. Proces decyzyjny projektowania/planowania, obejmujący realizację i użytkowanie, wymaga udziału wszystkich interesariuszy. Efekt synergetyczny zależy od partycypacji społecznej. 3) Synergia ekonomii społecznej. Partnerstwo prywatnopubliczne, poprzez synergię prowadzi do efektu „dźwigni” w finansowaniu inwestycji. Udana partycypacja wymaga istnienia społeczeństwa obywatelskiego. W praktyce uzyskanie efektu wymaga katalizatora, behawioralnej interwencji publicznej (BIP) pośrednika między interesariuszami, którymi są użytkownicy i zespołem projektowym/planistycznym/ realizacyjnym. Wynikiem działania projektowego/planistycznego jest krajobraz miasta, także terenów otwartych. Krajobraz pozwala na diagnozę dobrostanu gospodarki i społeczeństwa (Pawlikowski, Bogdanowski). Społeczeństwo obywatelskie przejawia patriotyzm pejzażu (Mackiewicz). Podano przykłady działań pozbawionych synergii, jak też z założenia synergetycznych.

Słowa kluczowe: krajobraz, partycypacja, patriotyzm pejzażu, planowanie urbanistyczne, projektowanie architektoniczne, społeczeństwo obywatelskie, synergia.

\section{Synergia/synergetyka. Uwagi wstępne}

Dawno człowiek zauważył, że praca wykonywana razem z innymi ludźmi daje efekty o większym zakresie niż praca w pojedynkę. Pojęcie synergii było w świadomości od zawsze, a termin, pod względem słownikowym, był dla starożytnych Greków oczywisty. Zestawienie słów syn - „razem” i ergon - „praca, dzieło, działanie” odnosiło się wprost do współdziałania. W okresie nowożytnym termin pojawia się w odniesieniu do doktryny teologicznej w 1657, a szersze zastosowanie w języku angielskim znajdować poczyna około 1925 .

Dzisiaj termin synergia jest używany w stosunku do wielu zjawisk w różnych dziedzinach. Spopularyzowało się rozumienie synergii jako zjawiska polegającego na interakcji dwóch lub więcej czynników lub sił w taki sposób, że łączny efekt ich działania jest większy od prostej sumy ich indywidualnych osiągnięć. Inaczej, w odniesieniu 
do ludzi: synergia to polegająca na współpracy interakcja grup, która wytwarza zintensyfikowany łączny efekt, większy niż taki, który byłby wynikiem ich oddzielnej pracy.

Obok pojęcia synergii pojawia się też pojęcie synergetyki. Oba terminy są dość luźno określone. Można przyjąć, że synergia to określenie charakteryzujące efekty działania, a synergetyka to ujęcie teoretyczne zjawiska przez naukę. Tatiana Berseniewa (2013) zauważa, że synergetyka „to nowy sposób patrzenia na świat i człowieka na siebie w tym świecie", to uogólnienie zjawiska synergii, jego teoria i uniwersalna metodologia naukowa. Jej przedmiotem są prawa samoorganizacji świata.

Richard Buckminster Fuller aby pokazać konieczność, ale też i istnienie synergii zauważa, że „wytrzymałość na rozciąganie stali chromo-niklowej jest 100 tysięcy razy większa od sumy wytrzymałości każdego z elementów stopu". Stwierdza też, że pojedynczy człowiek nie jest w stanie zbudować parostatku Queen Mary ${ }^{1}$. Wymaga to bowiem pracy wielu ludzi. Tylko łącząc się w wysiłku z innymi może osiągnąć tak złożony cel. Dotyczy to również złożonej dziedziny jaką jest architektura, jej projektowanie i realizowanie. Dlatego dyskutujemy synergię, czyli kto z kim ma/powinien współpracować, próbując wskazać gdzie może leżeć wartość dodana - efekt synergii.

\section{Spojrzenie wstecz - historia}

Praktyczne zastosowanie pojęcia synergii miało miejsce w literaturze naukowej dopiero w XX wieku. Böhm (1981) zauważa, że Patrick Geddes (1915) odnosi się do synergii. Jak pisze Böhm:

,[Geddes] pod wpływem syntetycznych metod badawczych Le Playa przedstawił formułę procesów życiowych, opartą na trzech elementach: środowisko, działanie, organizm. Strona bierna tej formuły (Place, Work, Folk) znalazła później odbicie w Karcie Ateńskiej jako „mieszkanie”, ,praca”, „wypoczynek”. Natomiast w stronie czynnej (Achievement, Synergy, Etho-Polity) spotykamy po raz pierwszy termin synergia. Pojęcie to thumaczone jest jako synteza energii i reprezentuje nowe pryncypia w pracy naukowej. Autor zwraca uwagę na ograniczoną przydatność analizy, podnosząc zarazem znaczenie kompleksowych rozważań. Wyraża to w zdaniu: „ekspansja bez integracji jest dezintegracją, bezkształtną degeneracją." (Böhm 1981, s. 18-19)

Wołanie Geddesa o integrowanie studiów urbanistycznych, poszerzonych o badania historyczne, geograficzne, demograficzne i socjologiczne, oraz o syntezę myśli, która doprowadzi do syntezy energii przez wielu bywały uważane za niemożliwe. „Smutnym paradoksem stał się natomiast fakt, że idea syntezy Miejsca, Pracy i Ludzi znalazła swe odbicie w Karcie Ateńskiej w postaci segregacji domu, pracy i wypoczynku.",2

Pojęcie i termin: synergia z wolna zaczęły zyskiwać popularność w latach 60 . XX w. Van Lier (1962) w książce Nowy wiek $^{3}$ zauważył, że technika (maszyna) wkracza w tytułowy nowy, trzeci wiek. Technika nie czerpie już energii, z mięśni człowieka, czy

\footnotetext{
1 „Wszelkie narzędzia można podzielić na dwie grupy: rzemieślnicze, możliwe do wykonania przez jednego człowieka zaczynającego samotnie w puszczy, oraz narzędzia przemysłowe, które nie mogą być wyprodukowane przez jednego człowieka jak np. S/S Queen Mary." (Buckminster Fuller 1969; thum. - J-KL).

2 Böhm 1981, s. 122-123.

${ }^{3}$ H. Van Lier w Le Nouvel Âge (1962) (polskie wydanie „Nowy wiek”. PIW, BMW, Warszawa 1970). „Świat techniki - pisze Van Lier - ulegając naturalizacji, technicyzuje jednocześnie naturę. Nie jest on przy tym trzecim królestwem obok natury i człowieka, ponieważ nie pojawia się, aby jedynie uzupełnić dwa poprzednie. Jest tym, co nazwaliśmy terminem niezręcznym, bo nie odpowiadającym owej jedności - rzeczywistością pośrednią".
} 
z natury, jak w pierwszym wieku, kiedy narzędziami był młotek i wiatrak. Nie dominuje też nad człowiekiem, jako maszyna parowa, czy wielki piec $\mathrm{w}$ drugim wieku, ale jest obecnie (czyli wieku trzecim) w synergii zarówno z człowiekiem jak i z naturą.

Dla Richarda Buckminstera Fullera synergetyka jest empirycznym studium systemów w transformacji, z naciskiem na zachowania całego system, które nie mogą być przewidziane na podstawie zachowań każdego ze składników $\mathrm{z}$ osobna, w tym uwzględniając rolę człowieka jako zarówno uczestnika jak i obserwatora. Ponieważ systemy są identyfikowane w każdej skali od poziomu najmniejszej jednostki do kosmicznego, a ludzkość zarówno artykułuje zachowanie tych systemów jak też i sama jest z tych systemów złożona, synergetyka jest bardzo szeroką dyscypliną. Obejmuje szeroki zakres studiów naukowych i filozoficznych w tym geometrię czworościanów i najgęstszego upakowania kul, termodynamikę, chemię, psychologię, biochemię, ekonomię, filozofię i teologię. Buckminster Fuller podjął trud zdefiniowania jej zakresu w swojej dwutomowej pracy Synergetics ${ }^{4}$ ("Synergetyka"). Jego dzieło zainspirowało wielu badaczy do zajęcia się gałęziami synergetyki, takimi, jak: samoorganizujące się struktury otwartych systemów dalekich od równowagi termodynamicznej, geometria czworościanów i dwudziestościanów, czy problemy geodezyjne w kontekście dynamiki społecznej.

Trzeba jednak stwierdzić, że pomimo głosów oficjalnego poparcia (artykuły Arthura Loeba) i nazwanie pewnej molekuły "buckminsterfullerenem", synergetyka pozostaje przedmiotem ignorowanym przez większość programów nauczania tradycyjnych wydziałów akademickich, a wielu badaczy świadomie dystansuje się od szerokiej, wszechogarniającej definicji Fullera, stojąc wobec problematycznego zamiaru zróżnicowania i zrelatywizowania wszystkich aspektów rzeczywistości.

W innych dyscyplinach nauk ścisłych, Hermann Haken traktuje synergetykę jako naukę interdyscyplinarną badającą formowanie się i samorzutną organizację wzorców i struktur $\mathrm{w}$ otwartych systemach dalekich od równowagi termodynamicznej. Hakena zainspirowała teoria lasera. Interpretacja przez Hakena zasad lasera jako samoorganizacji niestabilnych systemów wyznaczyła drogę do rozwoju synergetyki w końcówce lat 60. Stąd Haken jest uważany za jej twórcę 5 .

Synergetyka hakenowska dotyczy złożonych systemów, które przynależą do rozmaitych dziedzin, takich jak fizyka, meteorologia, chemia, biologia, nauka o ruchu, działanie mózgu, nauki komputerowe, socjologia (np. rozwój miast), psychologii i psychiatrii (w tym psychologii postaci ${ }^{6}$ ). Obecnie badania czynności koncentrują się na teorii mózgu i psychologii. Haken jest też wydawcą serii wydawniczej Springer Series in Synergetics ${ }^{7}$.

\footnotetext{
${ }^{4}$ R. Buckminster Fuller: Synergetics: Explorations in the Geometry of Thinking ("Synergia: Studia z geometrii myślenia", I wydanie 1975) oraz Synergetics 2: Explorations in the Geometry of Thinking ("Synergia 2: Studia z geometrii myślenia", I wydanie 1979).

5 Por. H. Haken: Erfolgsgeheimnis der Natur. Synergetik: die Lehre vom Zusammenwirken. Deutsche Verlags-Anstalt, 1981, przetłumaczona na język angielski jako The Science of Structure: Synergetics ("Synergetyka - nauka o strukturze"). O szerokim spojrzeniu Hakena na synergetykę świadczy jego zainteresowanie innymi dziedzinami, np.: H. Haken, G. Schiepek: Synergetik in der Psychologie: Selbstorganisation verstehen und gestalten. Hogrefe Verlag, 2006.

${ }^{6}$ Należy zauważyć ten powrót zainteresowania psychologią postaci w kontekście pracy Żórawskiego (1962) dotyczącej percepcji architektury.

${ }^{7}$ Od 1977 r. ukazało się 69 tomów, poczynając od: Haken H.: Synergetics, A Workshop. Proceedings of the International Workshop on Synergetics at Schloss Elman, Bavaria May 1977. Edited by H. Haken, Springer-Verlag 1977.
} 
Psychologiczne podejście do synergii prezentuje m.in. Ivan S. Banki ${ }^{8}$, który określa synergię jako sumę wektorów, którymi mogą być idee, postawy, działania, popędy, wysiłki poszczególnych członków grupy zmierzających do osiągnięcia jakiegoś celu.

W Polsce pierwsze publikacje związane z synergią pojawiają się na początku lat 70. Tadeusz Pszczołowski (1973) mówi o efekcie facylitacyjnym i organizacyjnym jako przypadkach synergii. Przywołuje wcześniejsze wypowiedzi Tadeusza Kotarbińskiego, także S. Kowalewskiego, który za A. Zaleznikiem, pisał, że synergia może mieć także ocenę negatywną i służyć „rozparcelowaniu konfliktu”. T. Kotarbiński stwierdził:

„pragnę rozważyć pewne swoiście prakseologiczne pojęcie synergii. Synergia będzie wtedy i tylko wtedy, gdy podmioty działające, jeśli współdziałają osiągną więcej niż jeśli działają każdy z osobna. (...) Można by odróżnić w synergii katalize w sensie swoiście prakseologicznym. Miałoby się z nią do czynienia, ilekroć podmiot działający osiąga więcej przy danym sposobie działania, jeżeli działa w asystencji innego podmiotu działającego. Asystencja polega na pewnym oddziaływaniu podmiotu asystującego na podmiot, któremu on asystuje, nie zawierającym określonego rodzaju jego działań. Tak np. podmiot zbiorowy w postaci grona obserwatorów meczu piłki nożnej oddziałuje w sposób ważny dla wyniku gry, na inny podmiot zbiorowy, mianowicie na zespół graczy, chociaż obserwatorzy nie popychają piłki"9.

W tej wypowiedzi Kotarbińskiego warto zwrócić uwagę na pojęcie „asystencji”, która „katalizuje” efekt synergetyczny. Ma to bardzo istotne znaczenie w procesie projektowania/planowania, o czym będzie mowa dalej. W odniesieniu do problemów architektury i urbanistyki, heroldami pojęcia synergii w Polsce byli, jak się zdaje, Lenartowicz (1973) w recenzji książki Buckminstera Fullera (1969) i Böhm (1976) ${ }^{10}$, $(1979)^{11},(1981)$.

\section{Synergia formy przestrzennej}

Böhm (1981) synergię - jako syntezę energii oznaczającą współdziałanie - odnosi do przestrzeni urbanistycznej. Stwierdza, że w architekturze współdziałanie objawia się w postaci „wnętrza”, takiego np. jak „działka”, ,ulica”, „miasto”. Jest to rodzaj kompozycji, która, zdaniem autora, reprezentuje wyższą jakość od zestawów wolno stojących elementów, takich jak „,blok”, „osiedle”, „,aglomeracja”. Owa wyższa jakość czytelna jest w krajobrazie miasta, które jest wyrazistą formą na tle, kompozycją dającą poczucie orientacji w przestrzeni oraz podstawy więzi emocjonalnej mieszkańców z ich miejscem. Oznacza to szeroko pojmowaną rewaloryzację - już nie tylko konkretnych miast zabytkowych, ale sztuki planowania miast - również współczesnych (Böhm 1981, s. 174)

Poszukiwanie śladów synergii w architekturze i przekształcanie różnorodnych przesłanek łączenia przestrzeni w spójną zasadę wymaga według Böhma bardzo szerokiego ujęcia, w ramach którego można wyróżnić wiele nurtów badań. Każdy z nich dostarcza pewnej porcji danych. W ich ocenie powtarzają się, w różnych proporcjach, najwyższe wartości wyróżniane w kulturze Zachodu, tj. dobro, prawda i piękno ${ }^{12}$.

\footnotetext{
${ }^{8}$ Banki, Ivan S.: The dictionary of administration \& supervision. Systems Research Institute1971.

Cytat według Pszczołowskiego (1973), s. 52 (podkr. - JKL).

${ }^{10}$ Böhm, A. (1976), „Architektura synergiczna”. Referat na posiedzeniu Komisji UiA O/PAN w Krakowie. [W:] Sprawozdania z posiedzeń komisji PAN O/Kraków.

${ }^{11}$ Böhm, A. (1979) „Elementy synergii w urbanistyce - ulica”. [W:] Teka Komisji Urbanistyki i Architektury O/PAN w Krakowie, t. XIII, Kraków.

${ }^{12}$ Por. Władysław Tatarkiewicz, przedmowa do: Żórawski (1962).
} 
Ład przestrzenny, podstawowe kryterium pracy, mieści po części wszystkie trzy wartości, znajdując swój zewnętrzny wyraz w pięknej formie. Zatem właśnie forma jest dla autora efektem synergii, a pozostałe jak niegdyś „,moc gruntowna, trwałość, wczas i wygoda"13 traktowane będą jako konieczne fundamenty dzieła architektury (Böhm 1981, s. 23)

Fundamentem ładu w przestrzeni miasta według Böhma jest wnętrze, a więc takie uformowanie elementów, które daje wrażenie zorganizowanej całości, a nie sumy składników - dowolnie powiększanej. Jego artykulacja jest działaniem w obrębie zdefiniowanej przestrzeni. Podziały wewnętrzne, prowadzone wciąż zgodnie z preferowanymi przez psychikę człowieka zasadami, nie atomizują więc postaci wnętrza, ale wzbogacają. Forma wnętrza ucieleśnia jego treść. Korelacyjny stosunek tych pojęć nie dopuszcza dowolnych przekształceń. Stąd nieprzystawalność treści zabudowy, jej braki lub przeciążenia prowadzić muszą do destrukcji wnętrza. Nie oznacza to jednak, aby w konsekwencji odrzucać w ogólności zasadę wnętrzowej struktury miasta.

(...) Zbliżenie, a następnie zintegrowanie elementów przestrzeni miasta dać może w przypadku zachowania właściwych proporcji, czyli innymi słowami znów dzięki sztuce równowagi - trwały synergiczny związek jaki obserwowaliśmy w przypadku ulicy pozytywowej dopełnionej i działki pasmowo-dośrodkowej. Wszechstronne korzyści, płynące z tego układu, korzyści wykraczające poza wartości przestrzenne, a więc społeczne, kulturowe, jak choćby wspomniane tu narodziny uniwersytetu na ulicy miasta - nie mogą być, jak dotąd niczym przelicytowane. (Böhm 1981, s. 172)

Praca Böhma (1981) dotyczy przestrzeni otwartych w mieście, tworzących wnętrza (krajobrazowe). Autor nie zajmuje się problematyką społecznych uwarunkowań tych przestrzeni. Pozostają aktualne zagadnienia złożoności tej przestrzeni, jej wrażliwości na zmiany, ładu estetycznego i jego zagrożenia. Krajobraz i jego ład, jawią się jako najbardziej istotny odbiornik efektów działań synergetycznych w zakresie projektowania i planowania w architekturze, o czym będzie mowa dalej.

\section{Synergia dialogu społecznego $\mathrm{w}$ architekturze i urbanistyce}

Autor artykułu stawia tezę, że w dziedzinie architektury traktowanej szerzej niż tylko w aspekcie przestrzennym, lecz widzianej w pełnym spektrum zwłaszcza jako problematyka społeczna, nośnikiem synergii staje się partycypacja społeczna. W dalszym ciągu autor udowadnia to stanowisko.

Trudno dzisiaj pomijać aspekt społecznej partycypacji w tworzeniu i przekształcaniu przestrzeni. Mimo to potrzeba partycypacji - dialogu społecznego w projektowaniu i planowaniu $\mathrm{z}$ trudnością dochodzi do głosu $\mathrm{w}$ architektonicznym środowisku zawodowym, obciążonym tradycją modernizmu i wyzwolonej sztuki architektury. $\mathrm{Na}$ temat partycypacji powstało wiele opracowań zarówno teoretycznych, jak i dotyczących technik prowadzenia dialogu (np.: Sanoff (1978), (1979) i inne; Blundell, Jons, Petrescu, Till (2005); Pawłowska (2010); Miessen (2013); inne).

Architekt jest przyzwyczajony do współpracowania, ponieważ dzisiaj praca w dużych wielobranżowych zespołach projektowych wymusiła konieczność partnerskiego działania. Ta współpraca istnieje wewnątrz zespołów projektowych i zespołów wykonawczych. Gorzej jest ze współpracą z tymi, dla których projektowanie jest prowadzone. Stworzono techniki ułatwiające i umożliwiające partycypację społeczną w procesie

\footnotetext{
${ }^{13}$ Mieszkowski, Zygmunt, Podstawowe problemy architektury w traktatach polskich (pol. XVI - pocz. XIX w.). PWN, Warszawa 1970. Cytat według Böhma (1981).
} 
decyzyjnym projektowania i planowania. W Polsce jednak przez długi czas nie znajdowały i nadal nie znajdują one zrozumienia, nie mówiąc o potrzebie ich stosowania. Skutki tego są doskonale widoczne w krajobrazach miejskich.

\subsection{Problemy partycypacji w projektowaniu i planowaniu}

Na trudności charakterystyczne dla wprowadzania partycypacji zwraca uwagę Till (2006). Władze zarówno państwowe jak i samorządowe unikają wdrażania procedur partycypacyjnych, słusznie uważając, że oznacza to wydłużenie czasu postępowania i zwiększone koszty, przy czym efekty nie są zadowalające, i nie prowadzą do konsensusu. Symbolicznie można by tytułem książki Miessena (2013) określić wyobrażenie partycypacji, które powszechnie panuje - koszmar partycypacji. Taka postawa i pojmowanie wynika z braku umiejętności prowadzenia dialogu. W związku z tymi brakami nie można też oczekiwać wystąpieniu efektu synergicznego. W Polsce ${ }^{14}, \mathrm{w}$ osiedlach krakowskich, tak jak wszędzie, ma miejsce dominacja inwestora. Przyszłym mieszkańcom, raczej nabywcom, oferuje się informację ograniczoną do planu mieszkania, z zatajeniem orientacji względem stron świata, najbliższego sąsiedztwa już istniejącego (inne bloki), jak też planowanego. Klient nie ma żadnego wpływu na to, co go czeka. Abstrahujemy oczywiście od przypadków, że deweloper znika po zebraniu pierwszej wpłaty i przestaje budować. Powstają osiedla o poetyckich nazwach: Osiedle Europejskie, Zielone Wzgórza, itp., które to nazwy nie mają nic wspólnego z rzeczywistością.

\subsubsection{Ruczaj-pierwsze na świecie eksperymentalne osiedle bez zieleni}

„Ruczaj, czyli pierwsze na świecie eksperymentalne osiedle bez zieleni - tak brzmi slogan nowego profilu na Facebooku". To określenie krakowskiego osiedla mieszkaniowego satyrycznie opisuje betonowy krajobraz, zarazem ironicznie protestując przeciwko inicjatywom wprowadzenia zieleni wewnątrz osiedla.

„Na zabetonowanym osiedlu Krakowa, tam, gdzie obok bloku stoi kolejny blok, pomiędzy nimi zamiast trawnika jest betonowy chodnik, a w miejsce parku - parking (koniecznie zbyt mały i grodzony), gdzie z okien betonowych domów dech zapiera widok na gustowną betonową kratkę [ekranów akustycznych - dod. JKL] odgradzającą osiedle od asfaltowej drogi (ta ma już też wielu fanów na profilu AutostradaSkawina.pl.)"15

Paweł Kubicki w wywiadzie stwierdza, że:

„[u]rzędnikom brakuje zintegrowanej wiedzy o mieście. Nie tylko im. Zamknięci jesteśmy w wąskich dyscyplinach. Inżynier projektuje drogi, ale nie myśli o tym, jak ta droga wpływa na społeczną tkankę miasta. (...) Brakuje im zintegrowanej wiedzy łączącej osiągnięcia różnych dyscyplin, jak architektura, socjologia, polityka transportowa, kultura. To wszystko elementy składowe zrównoważonego miasta. Jeśli tego brakuje, powstają takie rzeczy jak AUTOSTRADA SKAWINA." 16

Przypadek krakowskiego osiedla jest wynikiem sposobu zaspokajania potrzeb mieszkaniowych ludności w Polsce, tj. poprzez działania deweloperów, w tym przypadku wyjątkowo spektakularnie posuniętego do granicy możliwości i wyobraźni.

\footnotetext{
${ }^{14}$ Por. Np. Krzysztof Skalski: „Programy rewitalizacji w Polsce. Bilans, perspektywy, zarządzanie”. [W:] Lenartowicz i Maciąg (2006), s. 441-476.

${ }^{15}$ M. Waluś, „Na Ruczaju wykwitła miłość na mur-beton”. Gazeta Wyborcza, Kraków, czwartek 25 lutego 2016, s. 2.

${ }^{16}$ https://www.facebook.com/AutostradaSkawina.
} 


\subsubsection{Spalarnia odpadów w Krakowie}

Inną historią godną uwagi jest proces powstawania spalarni odpadów komunalnych w Krakowie. Urząd miasta przez trzy lata w okresie 2007-2010 walczył z oporem mieszkańców, którzy protestowali przeciwko wznoszeniu tego obiektu w swoim sąsiedztwie. Niepełne próby thumaczenia tylko zaogniały ten opór. Nawet wycieczka aktywistów do Szwecji nie doprowadziła do zmiany stanowiska mieszkańców. Dopiero negocjowanie zysków towarzyszących, inwestycji drogowych i innych pozwoliły na uzyskanie zgody. Zmarnowano dużo czasu i energii zamiast umiejętnie wyprzedzająco przeprowadzić akcję informacyjną i rzetelnie poinformować mieszkańców.

\subsection{Przyklady synergii w projektowaniu/planowaniu w Polsce}

Partycypacja społeczna w projektowaniu i planowaniu, jeśli jest dobrze wykorzystana, staje się nośnikiem synergii. Osiągnięcie dialogu społecznego nie jest jednak proste i nie wprost też dochodzi do efektów rzeczywiście synergicznych, to znaczy przekraczających sumę poszczególnych wysiłków włożonych w przedsięwzięcie.

Jaskółką idei partycypacji w projektowaniu było pojawienie się prof. Henry'ego Sanoffa na warsztatach Wszechnicy Architektury Krakowskiego Oddziału SARP w r. 1987. Sanoff, autor szeregu tekstów z zakresu wdrażania partycypacji w projektowaniu, poprowadził wówczas warsztaty dla architektów i opiekunek dzieci z krakowskich przedszkoli. Podstawowym założeniem tego rodzaju działania jest przyjęcie, że każda strona ma swoją ekspertyzę, której nie posiada druga i że powinny być one równoprawnie uznane. Osoby mające bezpośredni codzienny kontakt z grupą dzieci w wieku 3-6 lat wiedzą więcej o potrzebach niż architekci, którzy z kolei przez ponad 5 lat zdobywali specyficzną wiedzę i umiejętności kształtowania przestrzeni ${ }^{17}$. Istotnym warunkiem dochodzenia do konsensusu jest język (kod) zrozumiały dla obu stron. Uczestnicy posługiwali się ikonami funkcji i siatką płaską dla negocjacji i ustalania relacji wzajemnych funkcji w przestrzeni.

\section{Projekt REGENTIF}

W latach 2003-2007 na Wydziale Architektury PK we współpracy z Centrum Transferu Technologii "Politechnika Krakowska" działał zespó $1^{18}$, który w ramach 5 . Programu Ramowego Unii Europejskiej był ze strony polskiej partnerem w międzynarodowym projekcie poświęconym poszukiwaniu innowacji i wypracowaniu ogólnych zasad w rewitalizacji terenów i obiektów poprzemysłowych, powojskowych i pokolejowych (Lenartowicz i Maciąg (red.) 2006; Lenartowicz i Maciąg (red.) 2007). Analizę oparto o heksagonalny model wyprzedzającej interwencji.

Innowacją wprowadzaną w projekcie jest postulat partycypacji społecznej w każdej fazie rozwoju projektu rewitalizacyjnego. Stąd partycypacja była działaniem, któremu poświęcono szczególną uwagę $\mathrm{w}$ przewidzianej w projekcie próbie wdrożeniowej (Lenartowicz 2006).

W ramach projektu przeprowadzono w ramach wdrożenia szereg warsztatowych zajęć, które miały na celu sprawdzenie skuteczności i przećwiczenie technik partycypacyjnych w Polsce. Przyjęto technikę EASW, którą wówczas zastosowano po raz pierwszy w kraju spoza Unii Europejskiej. Warsztaty EASW - European Awarness Scenario

\footnotetext{
${ }^{17}$ Por. M. Złowodzki: „Problemy partycypacji użytkowników. VI staż Wszechnicy Architektury krakowskiego oddziału SARP”. [W:]Czasopismo Techniczne, Architektura. Politechnika Krakowska -1993, z. 1-A, s. 87-100.

${ }^{18}$ J.-Krzysztof Lenartowicz, Diana Maciąg, Piotr Bujas, Piotr Czupryński; Anna Ostręga (AGH).
} 
Workshop (Europejskie Warsztaty Budzenia Świadomości i Tworzenia Scenariuszy) były prowadzone pod nadzorem włoskiego trenera na temat nowego użytkowania terenów odstępowanych wówczas przez Hutę Stalowa Wola na rzecz miasta ${ }^{19}$. Przeprowadzono akcję reklamującą imprezę i zgromadzono zainteresowanych reprezentujących szereg grup interesariuszy (zarząd HSW, władze miasta, organizacje pozarządowe, Lasy Państwowe, także mieszkańców). Jako dowód skuteczności działania, i rzeczywistego przepływu energii, atmosfery entuzjazmu w dochodzeniu do konsensusu, należy podać, że po zakończeniu projektu unijnego, zebrani w trakcie warsztatów zawiązali Stowarzyszenie im. Eugeniusza Kwiatkowskiego PARK POMYSŁÓW w Stalowej Woli (2007).

\section{Ustawa o rewitalizacji}

Pozytywnie należy ocenić uchwalenie od dawna oczekiwanej ustawy o rewitalizacji z 9 października 2015 r. (Dz. U. Z 3 listopada 2015, poz. 1777). Rozdział 2. tej ustawy jest poświęcony partycypacji społecznej. Jest tam mowa o zakresie partycypacji (przygotowanie, prowadzenie i ocena rewitalizacji w sposób zapewniający aktywny udział interesariuszy), a także o tym, na czym te aktywności mają polegać. M.in. chodzi nie tylko o zapewnienie udziału interesariuszy, ale również wspieranie inicjatyw zmierzających do zwiększenia udziału interesariuszy w przygotowaniu i realizacji gminnego planu rewitalizacji. Konsultacje społeczne mają polegać na zbieraniu opinii, a także spotkaniach, debatach, warsztatach, spacerach studyjnych, ankietach i wywiadach. Konsultacje mają być prowadzone w języku niespecjalistycznym. Forum współpracy i dialogu interesariuszy z organami gminy ma stanowić Komitet Rewitalizacji. Komitet będzie pełnił funkcję opiniodawczo-doradczą władz samorządowych.

W rozdz. 5 ustawa wprowadza pojęcie Specjalnej Strefy Rewitalizacji. Powstanie SSR między innymi zapewnia lokatorom powrót do tego samego lokalu, który zajmowali przed rewitalizacją. Ponadto umożliwia gminie udzielanie właścicielom nieruchomości dotacji do wysokości połowy nakładów na prace remontowe.

\section{Projekt „Pojezierze Tarnowskie”}

Projekt pod nazwą: „Wykorzystanie zasobów przyrodniczych i kulturowych subregionu tarnowskiego dla wykreowania markowego produktu turystycznego - Pojezierze Tarnowskie"20 został zgłoszony w Regionalnym Programie Operacyjnym Województwa Małopolskiego (perspektywa finansowa 2014-2020), jako innowacje w rewitalizacji terenów otwartych w Subregionie Tarnowskim.

Projekt dotyczy wykorzystania przemysłowej i poprzemysłowej spuścizny oraz potencjału przyrodniczego i kulturowego dla rozwoju społeczno-gospodarczego. Pojezierze Tarnowskie realizowane jest na bazie ok. 130 zbiorników poeksploatacyjnych

\footnotetext{
${ }^{19}$ Warsztaty techniką EASW przeprowadzono z tym samym zespołem również: 1) w gm. Bolesław (na temat przyszłego zagospodarowania stawów osadowych Działu Przeróbki Mechanicznej „OlkuszPomorzany” ZGH Bolesław, które służą do składowania odpadów poflotacyjnych, 2007); 2) w Trzebini (na temat zagospodarowania części terenu po Zakładach Metalurgicznych, znajdujących się w środku miasta, 2007). W ramach zajęć ze studentami WA Politechniki Krakowskiej przeprowadzono ograniczone EASW na temat zabudowy powierzchni b. PKWK Jawiszowice (wówczas należącej do Kompanii Węglowej jako Brzeszcze-Ruch II). Niestety współpraca z władzami miasta i gminy Brzeszcze nie była udana, a warsztaty ograniczyły się do dyskusji i głosowania w obrębie samej grupy studenckiej. Podobną próbę podjęto z grupami studenckimi z całej Polski w ramach spotkania projektu OSSA 2009 w Częstochowie na temat nowego zagospodarowania i użytkowania terenów Huty Częstochowa.

${ }^{20}$ Koordynatorem projektu jest Anna Ostręga - Wydział Górnictwa i Geoinżynierii Akademii Górniczo-Hutniczej w Krakowie.
} 
i retencyjnych, zlokalizowanych na obszarze stanowiących subregion tarnowski trzech powiatów, w 8 gminach: Borzęcin, Szczurowa, Radgoszcz, Radłów, Wierzchosławice, Lisia Góra i Żabno oraz Olesno. Do projektu zgłoszonych zostało 19 zbiorników, o powierzchni ok. 600 ha lustra wody. Zakłada się, że kolejne zbiorniki mogą być dołączane po spełnieniu określonych kryteriów. Projekt jest innowacyjnym w skali kraju przedsięwzięciem mającym na celu zintegrowanie zbiorników pogórniczych i inżynieryjnych z przyrodą i kulturą oraz połączenie ich szlakami tematycznymi i trasami rekreacyjnymi (rowerowymi, pieszymi, konnymi, narciarskimi i żeglownymi). Celem tego przedsięwzięcia jest rozwój przemysłów czasu wolnego - tworzenie miejsc pracy i wypoczynku dla lokalnych społeczności i turystów.

Zalążkiem pomysłu był fakt, że wspólna granica gmin Szczurowa i Borzęcin przebiega przez jeden ze zbiorników, co zmusiło obie gminy do podjęcia wspólnego działania. Została zlecona koncepcja architektoniczno-urbanistyczna ${ }^{21}$, która okazała się na tyle przekonywająca, że zainteresowanie jej realizacją wyraziły pozostałe wymienione gminy. Innowacja projektu polega na wykorzystaniu dziedzictwa kulturowego regionu, tj. takich postaci jak poeci i pisarze: A. Asnyk, J. Baran, T. Boy-Żeleński, L. Rydel, St. Wyspiański, S. Mrożek; premier W. Witos, rzeźbiarz i lotnik J. Wnęk, bł. K. Kózka, czy zalipiańskie malarki, co nadaje projektowi zasięg ponadregionalny. Istotne jest zatem holistyczne spojrzenie na subregion, wydobycie tkwiących w nim potencjałów i wykorzystanie ich dla tworzenia unikalnych ofert oraz harmonizowanie funkcji, tak aby się uzupełniały, a nie powielały. Wiele spójnie funkcjonujących projektów wywoła efekt synergii. Przewidziano obszary: Zagłębie Przyrodnicze, Wodny Park Kulturowy i Wodny Park Adrenaliny oraz trasy: Szlak Groteski, Szlak Sukcesji Przyrodniczej, Szlak Poezji. Atrakcyjność wodnych kompleksów podniesiona zostanie poprzez uwzględnienie w koncepcjach zasobów lokalnej kultury i infrastruktury przemysłowej oraz przyrody. Duża liczba zbiorników poeksploatacyjnych daje możliwość równoważenia interesów przyrody, człowieka i gospodarki.

13 stycznia 2016 został podpisany list intencyjny przez Wicemarszałka Województwa Małopolskiego i beneficjentów projektu „Pojezierze Tarnowskie”. Byłby to w kategoriach synergetycznych największy obszarowo pojedynczy projekt krajobrazowy oparty na współpracy w Polsce, skalą zbliżający się do realizacji projektu SEE (20002010) na Pojezierzu Lubuskim w Niemczech.

\section{Katalizatory partycypacji jako narzędzie tworzenia synergii}

Omówiono przykłady niezręcznego postępowania w procesie projektowania/planowania, a także istniejącą już wiedzę i opracowania na temat przeciwdziałania niekorzystnym zjawiskom. Problemem pozostaje samo wdrażanie partycypacji w życie. Istnieje bowiem luka między produkcją wiedzy (nauką), a wykorzystaniem wiedzy (praktyką). Jak wspomniano, już Kotarbiński wyodrębniał w synergii funkcjonalne kategorie katalizy i asystencji. Dzisiaj przyjmują one postać postulowanych pośredników w procesie - brokerów wiedzy, których zadaniem są behawioralne interwencje publiczne (BIP). „BIP dają szansę na podniesienie skuteczności wielu działań publicznych" (Haber i Olejniczak (red.) 2014).

Takie skuteczne katalizatory istnieją już w Polsce w postaci pozarządowych organizacji pożytku publicznego, które przyjmują aktywną funkcję w procesie i łączą reprezentację interesariuszy z projektantem. To, jak wskazuje praktyka, daje oczekiwa-

${ }^{21}$ Biuro architektoniczne 55Architekci: Anna Szewczyk-Świątek i Wojciech Świątek. 
ne wyzwolenie synergii, czego efekty są widoczne. Zwykle dotyczy to inicjatyw lokalnych w ograniczonej skali. Mieszkańcy organizują się, mogą też uzyskać pomoc wykwalifikowanej instytucji pozarządowej, specjalizującej się w asystowaniu procesowi programowania, projektowania i realizacji.

Do takich należy Fundacja Napraw Sobie Miasto - organizacja pozarządowa www.naprawsobiemiasto z siedzibą w Katowicach (działająca od 2010). Fundacja zajmuje się badaniem oraz przetwarzaniem styku przestrzeń miejska - społeczność miasta (mieszkańcy i użytkownicy). Prowadzi warsztaty projektowe, stawia społecznościowe mapy internetowe i bazy danych przestrzennych. Pisze o teorii zarządzania urbanistycznego, historii planowania i projektowania oraz przemianach naszego otoczenia. Organizuje również wydarzenia, których celem jest popularyzowanie wiedzy o mieście: spacery, wycieczki oraz festyny sąsiedzkie. Razem z innymi ludźmi i grupami stara się wpływać na zmianę polityki przestrzennej samorządu. Przeprowadziła szereg projektów. Ich produktem są: warsztaty planowania partycypacyjnego "Nasza Przestrzeń".

Fundacja przygotowuje każdy z etapów (zaznaczony na czerwono), w których uczestniczy społeczność. 0. Zgłoszenie tematu. 1. Analizy. Proces zaczynamy od przeprowadzenia dwuetapowej analizy. Pierwszą - wewnętrzną - robimy sami. Sięgamy wówczas do map, baz danych i różnych dokumentów. Drugą - zewnętrzną - przeprowadzamy z udziałem mieszkańców danego miejsca, których może dotyczyć badany temat. Wyniki naszej pracy porządkujemy i zapisujemy w raporcie. 2. Warsztaty. Drugi krok to warsztaty, które przygotowuje i prowadzi specjalny zespół Fundacji. Na spotkanie zapraszamy osoby, które reprezentują uczestników etapu analiz. Pod okiem moderatorów uczestnicy opracowują różne, wariantowe pomysły na zagospodarowanie i użytkowanie miejsca. - Pomysły - 3. Debata. Trzecim elementem jest debata. Na początku przekazujemy informacje zgromadzone w trakcie warsztatów. Później dyskutujemy o wspólnej wizji, którą staramy się zapisać w postaci wspólnej koncepcji. Jednocześnie pomagamy wybrać opiekunów merytorycznych, którzy będą zarządzali inwestycją. Wszystkie informacje zbieramy w raporcie lokalnym. - wspólna koncepcja - wybór opiekunów inwestycji - 4. Realizacja. Proces zamykamy przekazując grupie opiekunów wszystkie materiały. Rola zespołu Fundacji zostaje ograniczona wyłącznie do wsparcia merytorycznego. Teraz to od opiekunów inwestycji w największym stopniu zależy, czy obszar zmieni się na lepsze ${ }^{22}$.

Działalność Fundacji NaprawSobieMiasto i jej podobnych instytucji i zespołów polega na katalizowaniu procesu projektowego (oby również i planistycznego), w którym Fundacja gra rolę asystenta, akuszera dobrego, a może lepszego projektu. Takiego działania zabrakło w krakowskich przypadkach.

\section{Synergia ekonomii społecznej}

Efekty synergetyczne osiągalne są także w zakresie efektów ekonomicznych, wymiernych pod względem finansowym. Partnerstwo prywatno-publiczne pozwala na wykorzystanie tzw. efektu „dźwigni”, który przy wkładzie (np. z budżetu gminy) równym jeden, może być podwajany a nawet potrajany przez własny udział użytkowników, czy przyszłych inwestorów. Są w Polsce przykłady dobrych praktyk i skutecznych synergicznych działań. Miasto Sopot, gdzie wspólnotom mieszkańców była przyznawana refundacja części kosztów remontów całkowitych budynków wspólnot mieszkaniowych wraz z uporządkowaniem otoczenia, części kosztów remontów elewacji budynków mieszkalnych oraz części kosztów zagospodarowania posesji. Wspólnoty mieszkaniowe mogły

\footnotetext{
${ }^{22}$ Strona internetowa Fundacji Napraw Sobie Miasto.
} 
zaciągać kredyty hipoteczne, a miasto finansowało odsetki. Innym przykładem może być dzielnica Letnica w Gdańsku, katalizatorem rewitalizacji której był młody architekt.

Do końca miesiąca zakończy się remont wszystkich ulic i większości kamienic. Później mieszkańcy mają zaprojektować nowe podwórka. Część mieszkańców gdańskiej Letnicy wprowadziła się już do nowych, wyremontowanych lokali z kompletnie zmienionym układem pokoi, a niektórzy właśnie czekają, aż prace w ich budynkach się skończą. Tymczasem kilkanaście rodzin apelowało do urzędników, by układ mieszkań, podobnie jak nowo położone podłogi czy kafelki, nie został zmieniony ${ }^{23}$.

Projekty rewitalizacyjne tego rodzaju omawia czerpiący doświadczenia z dobrych praktyk we Francji Skalski (2008), definiując kryteria oceny merytorycznej projektu rewitalizacyjnego jako: kompleksowość i spójność wewnętrzna programu; trafność wyboru obszaru; ilość i charakter działań; stopień zaangażowania i liczba partnerów inwestycyjnych; stopień komunikacji społecznej.

Nader istotne jest zaangażowanie mieszkańców, którzy są uczestnikiem procesu. W przypadku rewitalizacji obowiązuje zasada inwestowania nie „w kamienie”, ale „w ludzi”. Chodzi bowiem nie (tyle) o odnowienie substancji budowlanej, co o utrzymanie mieszkańców na miejscu, niedopuszczenie do wyludnienia dzielnicy i jej gentryfikacji. Stąd wynika pozostawienie decyzji o sposobie wykorzystaniu finansowania na prace budowlane samym użytkownikom.

\section{Społeczeństwo obywatelskie}

Wydaje się, że istota sprawy w uruchamianiu partycypacji, a przez to uzyskiwanie efektów synergicznych, leży w posiadaniu przez społeczeństwo będące odbiorcą projektu cech społeczeństwa obywatelskiego (civil society). Partycypacja powstaje w interakcji twarzą w twarz ludzi, którzy uznają za wspólny pewien zespół wartości. Te wartości są powodem tego, że znaleźli się razem ${ }^{24}$. Ta interakcja czyni z nich obywateli, świadomych swoich praw, ale i spełniających swoje obowiązki. Obywatel dba o swoje otoczenie najbliższe i dalsze. Bierze udział $\mathrm{w}$ jego kształtowaniu i pielęgnuje osiągnięte efekty, wktórych planowaniu uczestniczył. Tak przejawia się synergia działań projektanta i użytkownika. Na nic zda się synergia w projektowaniu i realizacji, o ile jej efekty nie będą pielęgnowane w czasie. A to wymaga zaangażowania społeczeństwa obywatelskiego.

\section{Patriotyzm krajobrazu}

[... J]echałam kiedyś pociągiem do Ołomuńca, mijałam lasy pełne śmieci i nagle wszystko się skończyło, czyściutki las - wtedy wiedziałam, że to już Czechy. Polski chłop patriota wywozi do swojego polskiego patriotycznego lasu swoje patriotyczne śmieci, wysypuje i wraca do swojego patriotycznego domu. Wolałabym, żeby patriotyzm objawiał się tym, że nie wywiozę tych śmieci do swojego lasu, nie zatruję swojej rzeki ${ }^{25}$.

W wypowiedzi służącej za motto tego rozdziału poetka odnosi się do patriotyzmu. Sarkastycznie wskazuje na mało obywatelską postawę rzekomego patrioty. Słusznie wiąże patriotyzm z krajobrazem (lasem w tym przypadku). Pojęcia obywatelskości, patriotyzmu i krajobrazu łączą się bowiem ze sobą. Postawa obywatelska odbija się

\footnotetext{
${ }^{23} \mathrm{http}: / /$ gdansk.naszemiasto.pl/tag/rewitalizacja-letnicy.html

${ }^{24}$ Por.: Sanoff (1990).

${ }^{25}$ Z Ewą Lipską rozmawia Donata Subbotko [w:] MAGAZYN ŚWIĄTECZNY, sobota-niedziela, 3031 stycznia 2016. Gazeta Wyborcza: wyborcza.pl, s. 32.
} 
w krajobrazie. Francuskie słowo paysage będące połączeniem pays i image, a zatem oznaczające „obraz kraju”, Jan Gwalbert Pawlikowski przetłumaczył jako „lico ziemi”. Do tego określenia nawiązał później Janusz Bogdanowski, który słusznie uważa, że krajobraz - fizjonomia ziemi, bezkompromisowo odzwierciedla stan gospodarki i kultury, zdrowie, ale i wszystkie tej ziemi choroby i niedomagania. Tout est paysage stwierdza w tytule swojej książki Lucien Kroll.

Chory krajobraz - taki jak w wielu miejscach w Polsce - sygnalizuje brak społeczeństwa obywatelskiego, samolubne działania przeciwspołeczne, tym samym niepatriotyczne. Poszukując pozytywnych efektów synergii musimy odwołać się do patriotyzmu krajobrazu. Patriotyzm krajobrazu ${ }^{26}$ to standard zachowania obywatelskiego.

Sam termin zawdzięczamy Józefowi Mackiewiczowi. Odniesienie do podanego językiem poetyckim mackiewiczowskiego pojęcia „patriotyzmu pejzażu” pozwala zauważyć synergię formy przestrzennej, ekonomii społecznej, bycia obywatelem i partycypacji. Autor przeciwstawia patriotyzm doktrynalny i narodowy właśnie patriotyzmowi pejzażu:

„Są trzy rodzaje patriotyzmu. Patriotyzm narodowy, patriotyzm doktryny i patriotyzm pejzażu. Narodowy interesuje się tylko ludźmi zamieszkującymi dany pejzaż ale nie pejzażem. Doktrynalny, ani ludźmi ani pejzażem, tylko zaszczepieniem doktryny. Dopiero patriotyzm pejzażu [...] obejmuje całość, bo i powietrze, i lasy, i pola, i błota, i człowieka jako część składową pejzażu."

I dalej:

„... narodowi patrioci, na przykład, dla nich największe szczęście ludzkości, żeby jak najwięcej ludzi mówiło koniecznie tym językiem, ale broń Boże nie innym. Albo gdzie na rynku stał kościół, postawić cerkiew. Albo: gdzie stała cerkiew, postawić przekoniecznie kościół. Zębami gotowi ściany szarpać. A dla niego - mówił - czy włoski barok, czy bizantyjska kopuła, i minaret, i synagoga, tak samo należą do pejzażu, jak jezioro, czy rzeka, czy rynek, przy którym stoją. I czapki, które zdejmują ludzie wchodząc do świątyni, czy właśnie nie zdejmując." 27

Patriotyzm pejzażu to kwintesencja obywatelskości. Obejmuje wszystkie skale, od pojedynczego człowieka po grupy ludzi i ich organizacje, od problemu niedopałka i psiej kupy na chodniku, przez nowo wznoszone budynki, po zabytki przeszłości; od ginącego motylka po lasy i parki narodowe.

Takie pojmowanie patriotyzmu nie opiera się na identyczności i wyłączności jakiejś pojedynczej charakterystyki (języka, czy wyznania, lub przekonań politycznych) danego obszaru, ale na akceptacji wszystkiego co na tym obszarze występuje. Mackiewicz odnosi się do krajobrazu kresów wschodnich II Rzeczypospolitej, a tam była mieszanka narodowości, religii, ubiorów, języków („Czy ktoś tu mówi po polsku?!” krzyczy pani Drużbacka na rynku w Rohatynie na Podolu, na początku opowieści Olgi Tokarczuk $^{28}$ ), a nade wszystko genów, które tworzyły niezwykłe bogactwo kulturowe. Ta mieszanina daje potęgę, która przewyższa sumę sił oddziaływania każdej grupy rozpatrywanej $\mathrm{z}$ osobna. A więc synergia krajobrazu traktowanego jako całość, w którym zapisanych jest wiele kontrastowych wątków. Obywatelskość polegająca na przestrzeganiu zasad demokracji i tolerancji dla różnych postaw i zachowań. W różno-

\footnotetext{
${ }^{26}$ Krajobraz - termin, być może po raz pierwszy w języku polskim, użyty przez Joachima Lelewela w "Dziejach Polski" - "do nich dwanaście krajobrazów", wyd. Warszawa, drukarnia J. Więckiego 1829.

${ }^{27}$ Józef Mackiewicz, Lewa wolna. (First published in 1965 by Polska Fundacja Kulturalna). Kontra, London 2012, s. 416-417.

${ }^{28}$ Olga Tokarczuk, Księgi Jakubowe. Wydawnictwo Literackie, Kraków 2014, ks. I, rozdz. 2, s. 883.
} 
rodności jest siła, dzięki której osiąga się efekt synergetyczny - skutek większy od wszystkich dodanych efektów poszczególnych działaczy.

\section{Zakończenie}

W artykule architektura jest traktowana jako szeroka dziedzina zajmująca się przestrzenią w której żyją ludzie, obejmująca również to, co nazywamy urbanistyką, a więc wszelkie przestrzenne wytwory jak też i sposoby ich realizowania, zwane odpowiednio projektowaniem i planowaniem. W podsumowaniu wypada powtórzyć, że w dziedzinie tak pojmowanej architektury, synergia pojawia się w wielu sytuacjach. Wskazano na trzy rodzaje: synergię związaną z samą formą przestrzenną, synergię społecznej ekonomii oraz synergię wynikającą z partycypacji społecznej. Uznano, że pojęciem całościowo łączącym różne rodzaje synergii jest krajobraz, pod warunkiem, że będzie on się spotykał z patriotyzmem.

\section{Literatura}

1. $\quad$ Berseneva T.P. Synergy. Synergetics. Dialectics. Cultures and Arts (Rosja) 5 (2013) 35-46.

2. Blundell Jons P., Petrescu D., Till J. Architecture and Participation. Spon Press, London 2005.

3. Böhm A. O budowie i synergii wnętrze urbanistycznych. Politechnika Krakowska, Kraków 1981.

4. Fuller R.B. Operating manual for the spaceship EARTH. Southern Illinois University Press, 1969.

5. Geddes P. Cities in Evolution. William \& Norgate, London 1915.

6. Haber A., Olejniczak K. (red.) (R)ewaluacja 2. Wiedza w działaniu. Polska Agencja Rozwoju Przedsiębiorczości, Warszawa 2014.

7. Lenartowicz K. Instrukcja obstugi statku kosmicznego Ziemia. Recenzja z książki R.B. Fullera Operating manual for the spaceship EARTH ["Instrukcja... "]. Architektura 5-6 (1973) 246-247.

8. Lenartowicz J.K. Architektura spoleczeństwa obywatelskiego. Zachowanie, Środowisko, Architektura / Behavior, Environment \& Architecture 1 (1998) 35-44.

9. Lenartowicz J.K. O społeczeństwie obywatelskim, partycypacji i terenach poprzemystowych. Lenartowicz, Maciąg (red.) 2006, s. 361-381.

10. Lenartowicz J.K. Estetyka spoleczeństwa obywatelskiego. K. Wilkoszewska (red.) Wizje i re-wizje. Wielka księga estetyki w Polsce. Universitas, Kraków 2007, s. 235-250.

11. Lenartowicz J.K. Zarzadzanie a społeczność lokalna - konflikt, wspótpraca czy przejęcie władzy? P. Kleczkowski (red.) Metody zarządzania odnową miast. DWN, Kraków 2008.

12. Lenartowicz J.K., Maciąg D. (red.) Od terenów przemystowych do .... Czasopismo Techniczne 8-A(103) (2006).

13. Lenartowicz J.K. Obywatel, architektura, estetyka, krajobraz, trwaty rozwój / The citizen, architecture, aesthetics, the landscape, sustainable development. Teka Komisji Urbanistyki i Architektury O/PAN w Krakowie XLII (2014) 255-274.

14. Lenartowicz J.K., Maciąg D. (red.): 2. Konferencja Regentif: Rewitalizacja miast poprzez regenerację terenów poprzemysłowych: innowacja i dobra praktyka. Materiały konferencji. Kraków, 30 maja - 1 czerwca 2007. Instytut Projektowania Architektonicznego Politechniki Krakowskiej, Kraków 2007.

15. Miessen M. Koszmar partycypacji (The Nightmare of Participation. Sternberg Press, 2010) wyd. polskie, Warszawa 2013.

16. Ostręga A., Lenartowicz J.K., Szewczyk-Świątek A., Świątek W., Cygan S. Rewitalizacja wyrobisk po eksploatacji piasków i żwirków z wykorzystaniem dziedzictwa przemysłowego $i$ kulturowego - przykład Borzęcina i Dołęgi. VII Międzynarodowa Konferencja Innowacyjne Rozwiązania Rewitalizacji Terenów Zdegradowanych, Ustroń 6-8 października 2014. 
17. Pawłowska K. (red.) Idea $i$ metody partycypacji społecznej $w$ ochronie krajobrazu $i$ ksztattowaniu przestrzeni. Tom A - Dlaczego? Tom B - Jak? Fundacja Partnerstwo dla Środowiska, Kraków 2010.

18. Pszczołowski T. Synergia i jej miejsce w teorii organizacji. Prakseologia 3-4(47-48) (1973) 45-53.

19. Sanoff H. Designing with Community Participation. Bowden, Hutchinson \& Ross, Stroudsburg, Penn. oraz McGraw-Hill, New York etc. 1978.

20. Sanoff H. Participatory Design. Theory and Techniques. Nakładem autora, Raleigh, NC 1990.

21. Skalski K. Komplementarność $i$ synergia projektów w Programach Rewitalizacji. Stowarzyszenie Forum Rewitalizacji Instytut Spraw Publicznych Uniwersytetu Jagiellońskiego. Kraków, 7 kwietnia 2008.

22. Till J. Negocjowanie nadziei. Lenartowicz \& Maciąg (red.) 2006, s. 384-408.

23. Ustawa o rewitalizacji z 9 października 2015 (Dz.U., poz. 1777).

24. Żórawski J. O budowie formy architektonicznej. Arkady, Warszawa 1962.

\title{
Synergy in architectural design and urban planning
}

\author{
J. Krzysztof Lenartowicz \\ Institute of Architectural Design, Faculty of Architecture, \\ Cracow University of Technology,e-mail: klenart@pk.edu.pl
}

\begin{abstract}
If the notion of synergy understood as cooperation has been functioning in human groups since time immemorial, modern philosophical and technical definitions of synergy as an interaction of various elements that when combined produce a total effect which is greater than the sum of the individual elements' actions was set up in the $20^{\text {th }}$ century (H. Van Lier 1962, H. Haken 1969, R. Buckminster Fuller 1969). Synergetics means a generalisation of synergy, a universal theory and methodology, the subject of which are the principles of the world self-organisation. In Poland first publications on synergy appear in the 1970s. (Kotarbiński, Lenartowicz, Pszczołowski, Böhm). The paper presents three types of synergy related to architectural design and urban planning: 1) the synergy of spatial form, the effect of which is spatial order, an organized formation of elements that create a whole. 2) the synergy of social dialogue. The decision making process of design / planning, including the realisation and use, requires involvement of all the key-players. A synergetic effect depends on social participation. 3) the synergy of social economy. Public-private partnership which through synergy leads to the lever effect in the financing of an investment. Existence of civil society is one of the conditions of a successful participation. To obtain a synergetic effect in practice one needs a catalyst, a behavioural public intervention (BPI) - an intermediary to act between the stakeholders, i.e. the users, and the design/planning/realisation team and to assist the development of the process. Landscape or cityscape is a result of the design/planning activity. Landscape allows for the diagnosis of the wellbeing of the economy and society (Pawlikowski, Bogdanowski). The patriotism of landscape is one of the manifestations of the civil society (J. Mackiewicz). Some cases deprived of synergy, as well good practices of synergetic character are presented.
\end{abstract}

Keywords: architecture, social participation, civil society, architectural design, urban planning, synergy, landscape patriotism. 